целью гарантировать защиту владельца от несанкционированного вмешательства со стороны институтов публичной власти (государства, институтов местного самоуправления). Только через принятие соответствующего закона можно обязать налогоплательщика перечислять часть своего дохода (имущества) в доход государства, не поднимая при этом конституционных гарантий неприкосновенности права частной собственности.

Ключевые слова: конституция, конституционное законодательство, конституционное право человека, налог, налогоплательщик, собственность, закон, государство.

\title{
Summary
}

Andriy Khudyk. The constitutional principle of establishing taxes and levies exclusively by the laws of Ukraine.

The article covers one of the aspects of the problem of constitutionalizing public finances in Ukraine, namely the legal construction and content of the fundamental, enshrined in the Constitution, principle of the legal regulation of the tax system of Ukraine - the principle of establishing taxes and levies exclusively by the laws of Ukraine. The article argues that state taxes and levies, in accordance with Article 67 of the Constitution of Ukraine, can be considered to be established by law if they are established by the proper subject, the legislative body, in the proper form of the law on amendments and additions to the Tax Code of Ukraine and in accordance with the procedure prescribed by law and enacted in accordance with the legislation in force. It is emphasized that the necessity of establishing taxes by the laws is dictated not so much by the task of ensuring the reality of their collecting and contributing to the budget as by the purpose of guaranteeing the protection of the owner from unauthorized interference by public authorities (the state and local selfgovernment institutions). Only through the adoption of the appropriate law one can oblige the taxpayer to transfer part of his revenue (property) to the state revenue, without violating the constitutional guarantees of the inviolability of the right of private property.

Taxing is a necessary condition for the existence of the state. The imposition of taxes by the law is of great practical importance due to public relations in the field of public finances. It is concluded that the constitutional purpose of the taxation system is to protect rights of property from public entities pursuits, which are limitless in principle, and to keep the balance of public needs and interests. From the standpoint of constitutional values, tax law is intended to limit the fiscal sovereignty of the state and to protect taxpayers from arbitrarily, groundlessly imposed taxes. The taxation system established by the law must have sufficient constitutional justification to determine clearly what specific part of the taxpayer's property a public entity can lay claim to and why. The establishment of taxes cannot be arbitrary, that is, taxes should not interfere with the exercise by individuals of their constitutional rights. Macro- and microeconomic implications both for the state and municipal budgets and for a particular taxpayer should be taken into account when establishing the tax and determining its essential elements.

Key words: constitution, constitutional legislation, constitutional human right, tax, taxpayer, property, law, state.

DOI: $10.36695 / 2219-5521.1 .2020 .25$

УДК $340.114: 342.4$

\section{І.Г. БИЧКОВ}

Іеор Геннадійович Бичков, здобувач Науководослідного інституту державного будівництва та місцевого самоврядування НАПрН України*

ORCID: 0000-0002-0523-9366

\section{КЕЛЬЗЕНІВСЬКА МОДЕЛЬ КОНСТИТУЦІЙНОЇ ЮРИСДИКЦІЇ ЯК ТЕОРЕТИЧНА ОСНОВА ЄВРОПЕЙСЬКОЇ СИСТЕМИ КОНСТИТУЦІЙНОГО ПРАВОСУДДЯ}

Постановка проблеми. Конституційний розвиток нашої країни так чи інакше сьогодні вже неможливий без урахування цілої низки фундаментальних правових доктрин, як-то «права та свободи людини», «правова держава», «верховенство права», «парламентаризм», «розподіл влади»1․ У зв’язку із цим для пошуку шляхів удосконалення системи влади та, зокрема, оптимальної моделі конституційної юрисдикції, особливого значення набуває вивчення надбань європейської доктрини конституційного правосуддя, однією з беззаперечно визначних сторінок якої є праці Г. Кельзена, що по праву вважається основоположником концепції конституційного суду та конституційного контролю в Європі.

Аналіз останніх досліджень і публікацій. Дану тематику досліджували та розкривали у своїх працях іноземні та вітчизняні вчені, а саме: К.М. Еррера, Я. Фольмайєр, О. Жуанжан, С.А. Авакьян, С.В. Боботов, М.В. Вітрук, В.О. Гергелійник, М.М. Гультай, С.В. Шевчук, М.І. Козюбра, В.П. Колісник, О.М. Мироненко, Т.П. Міхеєва, А.В. Портнов, М.В. Савчин, А.О. Селіванов, О.В. Скрипнюк, І.Д. Сліденко, П.Б. Стецюк, В.П. Тихий, Т.Я. Хабрієва, В.М. Шаповал, В.С. Чіркін, та багато інших. Водночас, не применшуючи внеску та значення цих та багатьох інших досліджень, зазначимо, що дискусійними залишається ще багато питань, які $€$ актуальними в науковому та практичному відношенні.

Формулювання мети статті. Виходячи 3 цих міркувань, мета даної статті полягає у дослідженні змісту моделі конституційної юрисдикції, запропонованої Г. Кельзеном, що свого часу фактично стала теоретичною основою сучасної європейської системи конституційного правосуддя, та визначенні основоположних елементів цієї моделі.

(C) І.Г. Бичков, 2020

* Igor Bichkov, Degree Seeking Applicant of Scientific Research Institute of State Building and Local Government of National Academy of Law Sciences of Ukraine 
Виклад основного матеріалу. Історія свідчить, що протягом XIX ст. в Свропі інститут конституційної юстиції не набув значного поширення. Це пов'язано передусім із тим, що переважна більшість країн на той час мала монархічну форму правління, природа якої не передбачала перевірку актів з точки зору їх конституційності. Водночас ідея конституційного правосуддя починає активно формуватися у тих європейських країнах, де розпочинались процеси переходу від абсолютизму до конституційної монархії. Зокрема, в Австрії після набрання чинності Конституції 1848 р., через потребу врегулювати відносини імперської адміністрації з адміністраціями імперських провінцій, було передбачено створення системи незалежної судової влади, зокрема органу конституційної юрисдикції - Вищого державного суду, який, щоправда, не був створений. Дещо пізніше, під час реформ 1867 р., в Конституції було закріплено правовий статус Імперського суду (Reichsgericht) як гаранта прав національних провінцій. Хоча первісні повноваження цього органу були обмежені розглядом вузького кола адміністративних питань (питань культури, асоціацій та спілок, висловлення національних поглядів), однак у процесі політичної боротьби за встановлення конституційної монарxiї (1885 р.) намітилась тенденція їх розширення. Зокрема, авторитетний вже тоді професор конституційного права Віденського Університету Г. Еллінек відкрито виступав за розширення повноважень Суду і підкреслював, що правовою може бути лише та держава, в якій законодавець так само підкоряється закону, як і звичайний громадянин ${ }^{2}$.

Наступним етапом розвитку конституційного правосуддя в Австрії, що став можливим в результаті розпаду Австро-Угорської імперії (30 жовтня 1918 р.) та оголошення першої Австрійської республіки (12 листопада 1918 р.), стало прийняття Національними зборами у 1919 р. Закону про Конституційний Суд Австрійської Республіки. До компетенції цього органу належало вирішення питань контролю за конституційністю законів, які приймали асамблеї провінцій. Таким чином, Суд став вищим гарантом Конституції держави $\mathrm{i}$ першою моделлю інституту спеціальної конституційної юрисдикції3. Існують і інші точки зору, зокрема, на думку професора О. Мироненка, перший спеціалізований орган конституційного правосуддя був утворений в Саксонії у 1831 р., оскільки розділ VIII Конституції Саксонії «Про охорону Конституції» передбачав створення Державного суду, до компетенції якого належало тлумачення Конституції та вирішення конституційних спорів між урядом і парламентом4.

Відповідні процеси перевірки конституційності законів судами поступово починали запроваджуватись і в інших європейських країнах, зокрема таких як Швейцарія (конституції 1848 та 1874 рp.). У Данії та Норвегії це відбувалось на підставі звичаю, без включення відповідних норм до Конституції. Так, у Норвегії перший випадок здійснення Верховним Судом перевірки конституційності закону мав місце у 1844 році. Існування конституційного контролю було передбачено також Конституцією Веймарської республіки (1919р.) у Німеччині та Конституцією Чехословаччини (1920р.).

Базові доктринальні підвалини відповідних процесів було закладено Дж. Локком та Ж.Ж. Руссо у природно-правовій концепції, що поставила питання відповідності актів державної влади вимогам більш високого порядку; Г. Спенсером у органічній теорії, згідно з якою вказані акти не повинні суперечити конституції, як акту установчої влади; Д. Остіном та іншими позитивістами, що вказували на структурний зв'язок позитивного права та особливе місце конституції у цій системі.

Водночас безпосереднім автором австрійської моделі судового контролю законодавства, яка в подальшому стала фактично зразком при запровадженні конституційного контролю у країнах континентальної Європи, у тому числі в Україні, став професор права Віденського університету Ганс Кельзен, який у роботі 1934 р. «Чисте правознавство» пропонує модифіковану позитивістську теорію, відповідно до якої замість мотивів страху перед сувереном запроваджується ідея правової норми, яка покладає обов'язки навіть на посадових осіб. Нормативно-правові акти за Г. Кельзеном формують подобу ієрархічної системи, в якій чинність нижчої норми визначається ії відповідністю вищій, або створення нижчої норми уповноважується існуванням вищої. Причому ієрархія норм розуміється як ієрархія приписів щодо застосування санкцій. Оскільки лише норми визначають чинність інших норм та їх розташування в межах правової системи, відповідно має існувати закон - норма найвищої юридичної сили, що визначає юридичну чинність усіх норм системи. Це і є основна норма (Grundnorm), найвища в будь-якій правовій системі, чинність якої приймається як аксіома 5 . Разом із тим, поряд із запропонованою концепцією праворозуміння, особливий інтерес у контексті нашого дослідження викликають саме інструментально-інституціональні пропозиції відомого теоретика права.

Як писав Г. Кельзен, конституція без реальних гарантій захисту від неконституційних актів не цілком обов'язкова в технічному сенсі. Ситуація, за якої неконституційні акти або неконституційні закони залишаються чинними, тому що їх неконституційність не призводить до їх скасування, більш-менш еквівалентна, 3 юридичного погляду, бажанню без зобов'язальної сили'.

Необхідність створення Конституційного Суду як єдиного органу конституційної юрисдикції для судового захисту конституції Г. Кельзен обгрунтовував на підставі трьох основних аргументів. По-перше, на думку видатного австрійського правознавця, умовою існування та належного функціонування конституційного правопорядку є логічна єдність, наявність якої забезпечується відповідністю всіх нормативно-правових актів Конституції як закону найвищої юридичної сили. Згідно з абз. 1 § 1 Конституції Чехословаччини 1920 р., яка була розроблена та прийнята під впливом Г. Кельзена, будь-який закон, що суперечить нормам конституції або законам, що іiі змінюють та доповнюють, $є$ нечинним. По-друге, як справедливо вважав Г. Кельзен, у ході реалізації власних повноважень та при виконанні конституційних завдань вищі державні органи можуть конфліктувати, а їх правові акти - суперечити Конституції. У результаті завдання Конституційного Суду полягає в тому, аби вирішувати можливі конфлікти відносно компетенції державних органів та констатувати нечинність виданих ними правових актів, якщо вони суперечать Конституції, тобто виконувати 
функції негативного законодавця. Саме через це, за Г. Кельзеном, Конституційний Суд є державним органом, що відрізняється від загальних судів як з точки зору місця в системі державних органів, так і функціонально7.

Ще одним важливим аргументом на користь необхідності створення Конституційного Суду, висловленим Г. Кельзеном, було покладення на нього функцій органу для захисту парламентської меншості від парламентської більшості: обмеження парламентської більшості та унеможливлення проявів іії свавілля. Якщо під сутністю демократії розуміти не всевладну більшість, а постійні домовленості між різними суспільними групами, представленими в парламенті більшістю та меншістю, а також засновану на цьому суспільну рівновагу, то Конституційний Суд є найбільш придатним органом для реалізації такої ідеї. Адже навіть сама по собі загроза звернення до Конституційного Суду може виявитися достатнім засобом меншості для запобігання антиконституційному порушенню з боку більшості тих інтересів, які захищаються правом, а отже, і для опору диктатурі більшості, що є такою ж загрозливою для суспільного спокою, як і диктатура меншості ${ }^{8}$.

Відповідно до концепції, викладеної Г. Кельзеном у низці праць, зокрема у роботі «Судовий контроль законодавства: порівняльне дослідження Австрійської та Американської Конституцій», конституційність законодавства може бути забезпечена двома окремими шляхами, обидва з яких були закріплені в Австрійській Конституції 1920 р.: особистою відповідальністю органу, що видав неконституційну норму, та незастосуванням неконституційної норми ${ }^{9}$. Незастосування конституційної норми могло бути досягнуто наділенням органів правозастосування повноваженнями щодо перевірки конституційності норми, яку вони повинні застосувати в конкретному випадку, та відмови у ії застосуванні в даному конкретному випадку, якщо є підстави вважати таку норму неконституційною. Подібний механізм фактично був запроваджений у Сполучених Штатах. Той факт, що правозастосовний орган визнає загальне правило неконституційним та не застосовує його в конкретному випадку, означав, що цей орган уповноважений позбавляти чинності загальне правило для конкретного випадку, і тільки для конкретного випадку, оскільки загальне правило як таке (нормативно-правовий акт) залишається чинним і може бути застосоване в інших конкретних випадках. Недоліком подібного запобіжника $є$ те, що різні органи правозастосування можуть мати різні думки щодо конституційності закону, в результаті чого один орган може застосувати його, оскільки вважатиме конституційним, у той час як інший орган відмовиться застосовувати через те, що вбачатиме ознаки неконституційності. Відсутність одностайності у вирішенні питання про те, чи є закон конституційним, тобто чи порушена конституція, містить велику небезпеку для авторитету конституції.

До набрання чинності Конституцією 1920 р. австрійські суди мали повноваження перевіряти конституційність законів тільки в разі, якщо розглядалось питання про належну публікацію останніх. Судовий контроль законодавства, таким чином, був можливий лише в дуже вузьких межах. Розширення цього інституту було одним із завдань конституційної реформи 1920 року. Наділення кожного окремого суду необмеженими повноваженнями щодо перевірки конституційності законів не було визнано доцільним. Вищезазначена небезпека неоднакового правозастосування при вирішенні конституційних питань була досить істотною, адже в Австрії, так само як і в інших країнах Європейського континенту, адміністративні органи не мали повноважень щодо перевірки конституційності законів, будучи зобов'язаними застосовувати закон, навіть у випадку, якщо суд, наприклад Верховний Суд (Oberster Gerichtshof), оголосив його неконституційним. Додамо до цього також і те, що в Австрії, як і в багатьох інших країнах Свропейського континенту, поряд із судами загальної юрисдикції функціонували також інші, зокрема адміністративні суди, які у власній практиці здійснювали правозастосування тих самих норм, що й суди загальної юрисдикції. Через це складно було повністю виключити можливість суперечностей між рішеннями адміністративних судів і судів загальної юрисдикції. Найважливіше значення мав однак той факт, що в Австрії рішення вищого суду загальної юрисдикції, так званого Oberster Gerichtshof, що стосувалися конституційності закону або указу, не мали обов’язкової сили для судів нижчої ланки. Останнім не було заборонено застосовувати закон, який Oberster Gerichtshof раніше оголосив неконституційним і який він, відповідно, відмовився застосувати в конкретній справі. Сам Oberster Gerichtshof не був пов'язаний правилом stare decisis. Отже, той самий закон, який у даному випадку був оголошений судом неконституційним, міг бути визнаний тим самим судом конституційним $\mathrm{i}$ застосований в іншому випадку. 3 цих причин централізація судового контролю законодавства була цілком доцільна в інтересах авторитету конституції.

Австрійська Конституція 1920 р. ст. ст. 137-148 гарантувала таку централізацію, покладаючи судовий контроль законодавства на спеціальний суд - так званий Конституційний Суд (Verfassungsgerichtshof). Поряд iз тим, Конституція наділяла відповідний суд повноваженнями анулювати закон у випадку, якщо вважатиме його неконституційним. Враховуючи, що закон досить рідко суперечить Конституції в цілому, у разі якщо неконституційне положення можна було відокремити від інших частин закону, суд мав можливість скасувати тільки таке положення. Відповідне рішення суду позбавляло чинності закон або відповідне окреме його положення не тільки для даного конкретного випадку, а й у цілому, на майбутнє. Із набуттям сили вказаним рішенням, анульований закон переставав існувати. Цікаво, що відповідне рішення Конституційного Суду діяло тільки з даного моменту, тобто за загальним правилом не мало ретроактивної сили ${ }^{10}$.

Оскільки рішення Конституційного Суду про анулювання закону фактично являло собою негативний акт законодавства, у певному сенсі для того часу можна було вважати, що Конституційний Суд виконував законодавчу функцію, закріплену за парламентом. Враховуючи це, Австрійська Конституція 1920 р. закріплювала, що члени Конституційного Суду обирались парламентом, на відміну від інших суддів, що призначались виконавчою владою. Через федеративний устрій парламент Австрії складався з двох палат: Національної ради (Nationalrat) та Федеральної ради (Bundesrat). У результаті, голова, заступник голови та половина членів Суду обирались Національною радою, у той час як інша половина суддів обиралась Федеральною радою (ст. 147 Конституції). Відповідний спосіб формування Конституційного Суду гарантував його макси- 
мальну незалежність від виконавчої влади, яка була особливо важливою при здійсненні контролю актів адміністрації, зокрема судового контролю указів голови держави, прем'єр-міністра та інших міністрів, що мали істотне політичне значення. Зловживаючи ними, виконавча влада могла розпустити парламент та усунути, таким чином, демократичні підвалини державності.

Яскравим історичним прикладом такого прецеденту стало зловживання ст. 48 Веймарської Конституції, яка уповноважувала уряд видавати укази, що стало способом знищення демократичного характеру республіки в Німеччині і підготовки приходу націонал-соціалістичного режиму. Відомо, що напівфашистська австрійська Конституція 1934 р. була запроваджена саме указом уряду. Підвалини для цього заклала і реформа австрійської конституції 1929 р., що не в останню чергу була спрямована проти Конституційного Суду, внаслідок конфлікту між ним та виконавчою владою. Хоча зміни не мали відношення до юрисдикції Суду, проте призвели до того, що його члени відтепер не обирались парламентом, а призначались адміністрацією (п. 65 Федерального закону від 7 грудня 1929 р., BGBI No. 392)11. Попередній склад Суду був фактично розпущений та замінений новим, усі члени якого були прибічниками адміністрації, що означило початок політичної еволюції, яка неминуче вела до фашизму та гарантувала те, що анексія Австрії нацистами не зустріла жодного супротиву.

Австрійська модель конституційної юрисдикції за Конституцією 1920 р. істотно відрізнялась від тогочасної американської з точки зору процедури визнання закону неконституційним. Так, згідно з Конституцією Сполучених Штатів, судовий контроль законодавства можливий лише в межах процесу, основна мета якого полягає не у з'ясуванні конституційності або неконституційності закону, а побічно, в умовах, коли сторона доводить, що застосування закону в конкретному випадку неправомірно порушує іiі інтереси через неконституційність закону. Тобто процедура конституційного контролю могла бути ініційована лише в контексті порушення інтересу сторони. Водночас інтерес конституційності законодавства, що носить публічний характер, не обов'язково збігається 3 приватними інтересами учасників справи. Такий інтерес заслуговує особливої процедури, зважаючи на свою особливу природу. Вразливість, зумовлена відсутністю відповідної процедури, свого часу активно дискутувалась у американській юридичній літературі ${ }^{12}$. Як наслідок, прогресивність моделі, запропонованої Г. Кельзеном, істотно випереджала існуючу до цього правову реальність.

Інститут судового конституційного контролю, згідно з першими європейськими конституціями ХХ ст. у країнах, де була сприйнята ідея Г. Кельзена, відрізнявся від американської моделі за обсягом повноважень: до Конституційного Суду могли звертатися лише певні, чітко визначені державні органи; неможливо було визначити антиконституційність державних правових актів, зокрема законів, на підставі порушення ними основних прав та свобод. Так, за Веймарською конституцією 1919 р. Конституційний Суд отримав: а) повноваження на здійснення процесу імпічменту, на вимогу парламенту, президента, канцлера або федерального міністра за будь-яке умисне порушення Конституції; б) повноваження на вирішення спорів 3 питань застосування суб'єктом федерації національного (федерального) права; в) повноваження на розгляд та вирішення конституційних компетенційних конфліктів між суб’ єктами федерації. Згідно з Конституцією Австрії 1920 р. до Конституційного Суду могли звернутись лише глава виконавчої влади для здійснення судового контролю щодо конституційності законів земель та уряди земель щодо конституційності федеральних законів 13 .

Більшістю європейських країн концепція Г. Кельзена була використана майже в чистому вигляді, за одним винятком: повноваження щодо безпосереднього захисту конституційних прав та свобод було надано окремому органу судової влади. Поширення відповідної моделі судового конституційного контролю та утворення конституційних судів припало на другу половину XX ст., коли потреба в запобіганні поверненню нацизму зумовила якісно новий рівень уваги до феномена конституційного правосуддя. Формування нових післявоєнних конституційно-демократичних режимів у Німеччині, Італії, Австрії, а дещо пізніше - в Іспанії та Греції, передбачало утворення зазначеного механізму шляхом наділення конституційних судів повноваженнями щодо захисту конституційних прав та свобод від узурпації публічної влади.

Висновки. Проведене дослідження допомагає зробити низку висновків. Активізація у другій половині XIX - першій половині XX ст. процесів переходу від абсолютизму до конституційної монархії, а згодом i республіканської форми правління, актуалізували значне підвищення уваги до моделі конституційної юрисдикції, запропонованої Г. Кельзеном. Сформульована відомим австрійським теоретиком права модель не просто передбачала інструментально-інституціональні пропозиції щодо створення нового органу публічної влади, а грунтувалась на визначеній Г. Кельзеном цілісній концепції праворозуміння, в основу якої було покладено ідеї ієрархічної правової системи, в якій чинність нижчої норми визначається і1і відповідністю вищій, або створення нижчої норми уповноважується існуванням вищої. Причому ієрархія норм ним розумілась як ієрархія приписів щодо застосування санкцій. У результаті умовою існування та належного функціонування конституційного правопорядку за Г. Кельзеном є логічна єдність, наявність якої забезпечується відповідністю всіх нормативно-правових актів Конституції як закону найвищої юридичної сили. Підтримання відповідного стану стає можливим завдяки діяльності спеціально утвореного органу конституційної юрисдикції, що відрізняється від загальних судів як з точки зору місця в системі державних органів, так $\mathrm{i}$ функціонально. Модель, запропонована Г. Кельзеном істотно випереджала існуючу правову реальність та була використана більшістю європейських країн майже в чистому вигляді, ставши своєрідною теоретичною основою сучасної європейської системи конституційного правосуддя, наступність якої знайшла пряме відображення і у вітчизняній моделі конституційної юстиції.

${ }^{1}$ Стецюк П.Б. Основи теорії конституції та конституціоналізму. Частина перша : посібник. Львів : Астролябія, 2003. 232 c. C. 48. 
2 Еллинек Г. Конституции, их история и значение в современном праве. Санкт-Петербург : Голос, 1906. 48 с. С. 6.

3 Козакевич О. Конституційний суд Австрії : факти. Юридичний вісник України. 2002. № 10. С. 12.

${ }^{4}$ Мироненко О. Джерела визрівання ідеї конституційної юстиції в Україні «Провансальського періоду»: світовий досвід, народолюбство, проєкти юридичних конституцій (перша половина XIX століття). Вісник Конституційного Суду України. 2000. № 5. C. 89-101. C. 89.

${ }^{5}$ Кельзен Г. Чисте Правознавство. 3 додатком: Проблема справедливості / пер. $з$ нім. О. Мокровольського. Київ : Юніверс, 2004. $496 \mathrm{c}$.

${ }^{6}$ Kelsen H. La garantie juridictionalle de la Constitution (la Justice constitutionnelle). Revue du Droit Public et de la Science Politique en France et a L'Etranger. Paris. 1928. P. 197-257. 226 p.

7 Шевчук С. Основи конституційної юриспруденції. Київ : Український центр правничих студій, 2001. 302 с. С. $239-240$.

${ }^{8}$ Kelsen H. La garantie juridictionalle de la Constitution (la Justice constitutionnelle). Revue du Droit Public et de la Science Politique en France et a L'Etranger. Paris. 1928. P. 197-257. 253 p.

${ }_{9}$ Кельзен Г. Судебный контроль законодательства: сравнительное исследование Австрийской и Американской Конституций. Правоведение. 2012. № 2. С. 190-202. С. 192.

10 Там само. С. 193.

11 Там само. С. 194.

12 Field Oliver P. The Effect of an Unconstitutional Statute. Minneapolis : University of Minnesota Press, 1935. xi, 355 p.

13 Шевчук С. Основи конституційної юриспруденції. Київ : Український центр правничих студій, 2001. 302 с. С. 240.

\section{Резюме}

Бичков І.Г. Кельзенівська модель конституційної юрисдикції як теоретична основа європейської системи конституційного правосуддя.

Стаття присвячена дослідженню змісту моделі конституційної юрисдикції, запропонованої Г. Кельзеном, що свого часу фактично стала теоретичною основою сучасної європейської системи конституційного правосуддя. Констатується, що сформульована відомим австрійським теоретиком права модель не лише передбачала інструментально-інституціональні пропозиції щодо створення нового органу публічної влади, а й одночасно втілювала визначену Кельзеном цілісну концепцію праворозуміння, в основу якої було покладено ідеї ієрархічної правової системи, єдність якої забезпечується відповідністю всіх нормативно-правових актів Конституції як закону найвищої юридичної сили. Обгрунтовано, що модель, запропонована Г. Кельзеном, істотно випереджала існуючу правову реальність та була використана більшістю європейських країн майже в чистому вигляді, зокрема знайшла пряме відображення у вітчизняній моделі конституційної юрисдикції. лізм.

Ключові слова: Г. Кельзен, конституційна юрисдикція, кельзенівська модель, конституційна юстиція, конституціона-

Резюме

Бычков И.Г. Кельзеновская модель конституционной юрисдикции как теоретическая основа европейской системы конституционного правосудия.

Статья посвящена исследованию содержания модели конституционной юрисдикции, предложенной Г. Кельзеном, в свое время фактически стала теоретической основой современной европейской системы конституционного правосудия. Констатируется, что сформулированная известным австрийским теоретиком права модель не только предусматривала инструментально-институциональные предложения по созданию нового органа публичной власти, но и одновременно воплощала определенную Г. Кельзеном целостную концепцию правопонимания, в основу которой были положены идеи иерархической правовой системы, единство которой обеспечивается соответствием всех нормативно-правовых актов Конституции как закону наивысшей юридической силы. Обосновано, что модель, предложенная Г. Кельзеном, существенно опережала существующую правовую реальность и была использована большинством европейских стран практически в чистом виде, в частности нашла прямое отражение в отечественной модели конституционной юрисдикции.

Ключевые слова: Г. Кельзен, конституционная юрисдикция, кельзеновская модель, конституционная юстиция, конституционализм.

\section{Summary}

Igor Bichkov. The Kelsen model of constitutional jurisdiction as the theoretical basis of the European system of constitutional justice.

The article is devoted to the study of the content of the model of constitutional jurisdiction proposed by H. Kelsen, which at one time actually became the theoretical basis of the modern European system of constitutional justice. It is stated that the model formulated by a well-known Austrian law theorist not only envisaged instrumental-institutional proposals for the creation of a new public authority, but also embodied the definite concept of common sense of law defined by Kelsen, which was based on the ideas of a hierarchical legal system acts of the Constitution as the law of the highest legal force. It is substantiated that the model proposed by H. Kelsen substantially outstripped the existing legal reality and was used almost in its purest form by most European countries, and in particular was directly reflected in the domestic model of constitutional jurisdiction.

It is noted that, according to Kelsen's concept in a number of papers, in particular in the Judicial Review of Legislation: A Comparative Study of the Austrian and American Constitutions, the constitutionality of legislation can be ensured in two separate ways, both of which were enshrined in the Austrian Constitution of 1920: the responsibility of the body that issued the unconstitutional norm and the non-application of the unconstitutional norm. Non-application of a constitutional rule could be achieved by giving law enforcement authorities the power to review the constitutionality of a rule they must apply in a particular case and refuse to apply it in that particular case, if there is reason to consider such a rule unconstitutional. A similar mechanism has actually been introduced in the United States. The fact that a law enforcement authority recognizes a general rule as unconstitutional and does not apply it in a particular case meant that that authority was empowered to revoke the general rule for a particular case, and only for a specific case, since the general rule as such (normative act) remains applicable and may be applied in other specific cases. The disadvantage of this fuse is that different law enforcement agencies may have differing views on the constitutionality of a law, whereby one authority can apply it as it considers constitutional, while another authority will refuse to apply it because it will see signs of unconstitutionality. The lack of unanimity in deciding whether a law is constitutional, that is, whether a constitution is violated, carries great danger for the authority of the constitution. 
In most European countries, it is stated that H. Kelsen's concept was used almost in its purest form, with one exception: the powers to directly protect constitutional rights and freedoms were given to a separate judicial authority. The extension of the appropriate model of judicial constitutional control and the formation of constitutional courts fell in the second half of the twentieth century, when the need to prevent the return of Nazism caused a qualitatively new level of attention to the phenomenon of constitutional justice. The formation of new post-war constitutional-democratic regimes in Germany, Italy, Austria, and later in Spain and Greece, provided for the creation of a mechanism by conferring on the constitutional courts powers to protect constitutional rights and freedoms from usurpation of public power.

Key words: H. Kelsen, constitutional jurisdiction, Kelsen model, constitutional justice, constitutionalism.

DOI: $10.36695 / 2219-5521.1 .2020 .26$

Удк 3453/45:123/63:5

\section{A.I. IPКЛІЄНKO}

Андрій Ігорович Ірклієнко, аспірант Інституту законодавства Верховної Ради України*

ORCID: 0000-0002-5689-2226

\section{ДВОПАЛАТНИЙ ПАРЛАМЕНТ В УМОВАХ ФОРМУВАННЯ КОНСТИТУЦІЙНОЇ ДЕМОКРАТІЇ}

Постановка проблеми. Парламентаризм, теоретичні витоки якого беруть початок у навчаннях про народний і національний суверенітети, цілком логічно пов'язаний з утвердженням принципів верховенства права і демократизму в суспільстві й державі, впровадженням ефективних механізмів гарантування конституційних прав людини, а також формуванням таких інститутів держави, які б забезпечували найбільш повне і всебічне здійснення його функцій та реалізацію потреб суспільства.

Аналіз останніх досліджень і публікацій засвідчив, що проблему двопалатного парламенту в Україні вивчали М.М. Воронов, О.В. Скрипнюк, Г.В. Зубенко, О.Д. Святоцький, Ю.М. Тодика та інші науковці.

Метою статті визначено аналіз особливостей становлення двопалатного парламенту в умовах конституційної демократії.

Виклад основного матеріалу. Свропогенна за своєю суттю ідеологія парламентаризму, вперше обгрунтована в працях таких мислителів, як Ж. Боден, Т. Гобі, Л. Дюгі, І. Кант, Д. Локк, Ш. Монтеск’є, А. Дайсі і багатьох інших, нині отримала свій розвиток не тільки в країнах з давніми традиціями народного представництва, а й у державах, де парламентаризм почав утверджуватися одночасно 3 першими конституціями і конституційними актами, починаючи з другої половини ХХ століття. Для пострадянських і постсоціалістичних країн ідеологія парламентаризму, після розпаду колишнього СРСР і руйнування радянської державно-правової доктрини, в основі якої лежала ідея домінування в державі «системи рад усіх рівнів» 1 , стала фундаментом їх демократичного інституційного розвитку й продовжує залишатися ним.

Український парламентаризм має давні історичні корені. Сучасні правознавці вважають предтечею національного парламентаризму вічову демократію і феодальні з’їди в Київській Русі, козацькі ради i козацьку демократію в загальному, діяльність Центральної Ради та навіть певною мірою «парламентаризм» радянської епохи. Втім, утвердження і розвиток повноцінного національного парламентаризму стало можливим лише після проголошення незалежності України в 1991 році².

За 28 років незалежності український парламентаризм мав певні досягнення й деякі прорахунки. При цьому XXI ст. поставило перед ним серйозні виклики, ставши своєрідним «екзаменатором» ефективності організації та діяльності національного парламенту в умовах конституційно-правової реформи, перші спроби здійснення якої можна пов'язати з проведенням всеукраїнського референдуму 16 квітня 2000 року. Нагадаємо, що цей референдум, серед іншого, мав на меті з'ясувати громадську думку щодо формування двопалатного парламенту, одна з палат якого представляла б інтереси регіонів України.

Не меншим випробуванням для вітчизняного парламентаризму стала й конституційно-правова реформа 2004-2008 рр., зміст якої передбачав перехід України до парламентсько-президентської форми правління, підвищення ролі й авторитету національного парламенту в державі і політично структурованому громадянському суспільстві країни ${ }^{3}$. На жаль, перманентна політико-правова криза останніх років не сприяла задоволенню високих запитів сучасного суспільства та здійснення належного законодавчого забезпечення новітніх державотворчих процесів в Україні.

Свідомо уникаючи політико-правових оцінок організації та діяльності Верховної Ради України V-VI скликань, вважаємо за доцільне зазначити, що вдосконалення концепції сучасного українського парламентаризму та оптимізація організації й діяльності національного парламенту нині є пріоритетним напрямом конституційної реформи в 2008 р. та наступних роках ${ }^{4}$. На нашу думку, одним із пріоритетних шляхів реформування українського парламентаризму сьогодні є запровадження бікамералізму як теорії і практики функціонування в державі двопалатного парламенту.

(C) А.І. Ірклієнко, 2020

* Andrey Irkliienko, Postgraduate student of the Institute of Legislation of the Verkhovna Rada of Ukraine 